\title{
Uncovering the Hidden Factors that Could Compromise Equitable and Effective Engineering Education
}

\author{
Idalis Villanueva, Ph.D. \\ Department of Engineering Education \\ Utah State University \\ Logan, Utah, USA \\ Joel Alejandro Mejia, Ph.D. \\ Department of General Engineering \\ University of San Diego \\ San Diego, CA, USA \\ Renata A. Revelo, Ph.D. \\ Department of Electrical \& Computer Engineering \\ University of Illinois at Chicago \\ Chicago, IL, USA
}

\begin{abstract}
Literacies are central to the social and cultural practices that are intertwined with identities, who gets to participate in engineering, and the knowledge that is valued in the discipline. However, identifying these literacies is not a straightforward process for engineering faculty. The purpose of this workshop is to help engineering faculty identify equityoriented literacies that challenge hidden curriculum frameworks in engineering and influence engineering identity formation.
\end{abstract}

Keywords-literacy, hidden curriculum, engineering identity

\section{INTRODUCTION}

Literacy plays a very important role in engineering education [1-5]. By examining critically not just how the students acquire knowledge but why and how "knowledge" is presented collectively in engineering, educators have an opportunity to challenge the dynamics and assumptions underlying specific normative practices in engineering that impact access, equity, and diversity in the field. In this workshop, participants will discuss and identify equity-oriented literacy instruction strategies through approaches based on hidden curriculum, literacy, and engineering identity. The production of viable engineering designs often depends in large part upon people's literacy practices, or their comprehension and creation of a variety of written, visual, and numeric texts. Through identification of important curriculum and pedagogical choices, literacies, and norms that can influence equitable engineering education, sustainable and more effective engineering education can occur in formal and informal educational settings.

\section{THEORETICAL FRAMEWORK}

Content taught in engineering classrooms plays an important role in the academic, personal, and professional development of the students. Often what counts as "objective" knowledge in some types of curriculum, such as engineering, is one-sided and ignores the realities of other disciplines and individuals participating in these classes[6]. The hidden curriculum, or the unspoken or implicit academic, social, and cultural messages communicated to students [7], is so powerful in engineering that an ethnocentric, male-dominated way of thinking has permeated through the engineering discipline $[8$, 9]. The content and practice of engineering has largely been established by White middle-class males who have ultimately decided what is "engineering" [10] and how it is best taught.

Thus, despite the wealth of research related to literacy in STEM education and its importance in achieving equity and acknowledging different ways of knowing, engineering literacy has not made great headway in engineering classrooms, possibly because it can be perceived as ill-fitted for the discipline [11]. We argue that by understanding engineering literacies, the comprehension and creation of written texts, and the ability to locate, evaluate, and produce discipline specific texts [1-5], engineering instructors can develop a pedagogy, curriculum, and classroom structures that offset the damaging features of the engineering hidden curriculum [6]. III. Goals of the special session

The goal of the session is to help engineering educators understand and gain awareness between what they teach in 
their formal curriculum (e.g., graphs, equations, HW) and their pedagogical choices, and in turn, what students learn, internalize and perceive from them. More specifically, we will elaborate on the literacy components of formal engineering education and how they may relate to hidden curriculum in engineering and engineering identity, as the literature suggests that these constructs are integral for an equitable and effective engineering education experience. The session will also present some strategies and guidelines that engineering educators can use to promote equity and effective engineering education, while accounting for the associations between literacy, hidden curriculum, and engineering identity.

\section{DESCRIPTION OF TOPICS AND ACTIVITIES}

The topic that brings all the elements of this special session together is equity and effective engineering education. After a 10-minute introduction on equity and effective engineering education, each group will discuss concepts and findings by the researchers. Each section is aimed to help the audience critically think about the practical ways of implementing these concepts in their own classrooms. All sessions are designed to be interactive and engaging to the audience. The first session will be conducted by the second author, Dr. Mejia.

\section{A. Dr. Mejia's Session: Literacy for Equitable and Effective Engineering Education}

The session will begin with a quick 5-minute synopsis of what literacy is, including some examples that are found in the engineering classroom (e.g., graphs, assignments). Then, an interactive and free online game that can be used in any tablet, cell phone, or computer called Kahoot!, will take place. In this activity, all members will be asked to log into Kahoot! No downloads are required for this activity and it is a free program that can be accessed via cell phone or tablets. Soon after all participants have entered the online game, a series of images regarding literacy will show up (six images in total will be shown). Participants will have 5 seconds to respond to each answer and scores will be tallied for each question. After the responses are shared with the audience, a small group discussion will take place and a final individual reflection activity will be shared with the participants.

\section{B. Dr. Revelo: Identity for Effective and Equitable Engineering Education}

In this session, participants will be provided with a quick 5minute introduction to engineering identity formation. Participants will be asked to provide responses to an online poll using PollEverywhere that ties to topic of identity formation. Again, no download is required for this activity and they can be accessed via cell phone or tablet. In this activity, participants will be asked to send their responses to 4 questions on identity (one based on community culture, one based on family, one based on individual latency, and one based on socialized experiences). Participants will have the option of sending their responses via text message or through the website. A group discussion will transpire and a final individual reflection activity will be shared with participants.

\section{Dr. Villanueva: Hidden curriculum for effective and equitable engineering education}

In this session, participants will be provided with a quick 5minute introduction to hidden curriculum in engineering. Participants will be asked to view a 4-5 minute video of a hypothetical scenario in an engineering classroom. The audience will have to use Kahoot! once more to identify with a character in the scene. A discussion will take place about each character and what they represent. Then, participants will be provided with blank poster boards where they can enter strategies for success for implementation of what has been learned in their classrooms. A group discussion will take place followed by a final individual reflection activity.

\section{Wrap up of the special session}

Once participants have learned about all three constructs (literacy, identity, and hidden curriculum), attendees would have prepared an individual reflection activity related to each session's topic. In the last 40 minutes of the workshop, attendees will be guided through a classroom-based scenarios or case studies where they will have to develop equity-aligned strategies to address literacy, hidden curriculum, and engineering identity development as they relate to the scenario. Depending on the size of the group, there will be 3-5 scenarios or cases shared with the attendees. There will be reporting out by group.

Finally, participants will complete a 2-3 items list of practical and simple strategies they can use in their own classes to promote equitable and effective engineering education. By having the attendees listing these items, they will become conscious and empowered to take action, if they desire, in their classes.

\section{ANTICIPATED AUDIENCE}

This special session is relevant to all FIE attendees. Advanced graduate students, engineering faculty, and faculty focused on K-16 engineering education might benefit the most from this session. Through this special session, we aim to present examples of effective engineering education strategies that can enhance and promote equity in the classrooms. We also posit that the audience will be interested in seeing examples of how to connect practices that aim to more effectively and equitably teach in the engineering classroom.

\section{SIGNIFICANCE}

Gee argued that positioning literacy as the "ability to write and read" situates literacy in individuals rather than in society [12]. It obscures the multiple ways in which literacy is connected not only to the ability to read and write but also to the dynamics of power. Literacies consider the ways in which different practices provide an opportunity to think, talk, write and participate in different discourses. Thus, literacies can be exclusive or inclusive and lead to practices that could impact the formation of engineers.

Engineers do not work in isolation - they participate in the creation of new knowledge but also utilize and contribute to the collective intelligence of others. Engineering, at its core, is 
an intensely social process $[13,14]$. Heywood argued that engineering is a profession that interconnects the science of making things and needs of society [14]. Such interconnectedness creates new problems for both engineers and educators, and urges the need for change. For engineers this means developing different skills and, in terms of engineering literacy and hidden curriculum, it involves understanding engineering processes, its technological outputs in relation to society, and how as educators we influence the formation of future engineers.

\section{FUTURE WORK}

Our future work includes the development of a model or framework that uses literacy, hidden curriculum, and engineering identity as a way to understand equitable engineering education. These sessions will help inform the development of these models for engineering educators.

\section{ACKNOWLEDGEMENTS}

This material is based upon work supported in part by the National Science Foundation (NSF) No. EEC- 1653140 to Villanueva and NSF No. 1644976 to Mejia. Any opinions, findings and conclusions or recommendations expressed in this material do not necessarily reflect those of NSF.

\section{REFERENCES}

[1] C. Sias, A. Wilson-Lopez, and J. Mejia, "Connecting students' background experiences to engineering design," Technology and Engineering Teacher, vol. 76, p. 30, 2016.

[2] A. A. Wilson, E. Smith, and D. L. Householder, "Using Disciplinary Literacies to Enhance Adolescents' Engineering Design Activity," Journal of Adolescent \& Adult Literacy, vol. 57, pp. 676-686, 2014.

[3] A. Wilson - Lopez and S. Gregory, "Integrating literacy and engineering instruction for young learners," The Reading Teacher, vol. 69, pp. 2533, 2015.

[4] A. Wilson-Lopez, C. Sias, and J. Mejia, "Fundamental literacies in English learners' engineering design work," 2015.

[5] M. Robinson and B. Kenny, "Engineering literacy in high school students," Bulletin of Science, Technology \& Society, vol. 23, pp. 95$101,2003$.

[6] H. A. Giroux and A. N. Penna, "Social education in the classroom: The dynamics of the hidden curriculum," Theory \& Research in Social Education, vol. 7, pp. 21-42, 1979.

[7] E. Margolis, The hidden curriculum in higher education: Psychology Press, 2001.

[8] K. L. Tonso, "The impact of cultural norms on women," Journal of Engineering Education, vol. 85, pp. 217-225, 1996.

[9] M. Walker, "Engineering identities," British Journal of Sociology of Education, vol. 22, pp. 75-89, 2001.

[10] D. Riley, A. Slaton, and A. Pawley, Social justice and inclusion: Women and minorities in engineering, Handbook of Engineering Education Research ed. New York, NY: Cambridge University Press, 2014.

[11] T. Shanahan and C. Shanahan, "What is disciplinary literacy and why does it matter?," Topics in language disorders, vol. 32, pp. 7-18, 2012.

[12] J. Gee, Social linguistics and literacies: Ideology in discourses: Routledge, 2015.

[13] L. L. Bucciarelli, Engineering philosophy: DUP Satellite; an imprint of Delft University Press, 2003.

[14] J. Heywood, Engineering education: Research and development in curriculum and instruction: John Wiley and Sons, 2005. 